\title{
JOINT RUSSIAN-MONGOLIAN STATEMENT
}

On January 13-14, 2004, Minister of Foreign Affairs of the Russian Federation Igor Ivanov paid an official visit to Mongolia at the invitation of Minister of Foreign Affairs of Mongolia Luvsangiin Erdenechuluun.

Ivanov was received by President of Mongolia Natsagiin Bagabandi and Prime Minister Nambaryn Enkhbayar and held talks with Erdenechuluun.

A thorough exchange of views on a broad spectrum of issues in bilateral relations and international and regional problems took place. The Sides reaffirmed their intention to strengthen the special character of RussianMongolian good-neighborly partnership relations, guided by the Treaty on Friendly Relations and Cooperation between the Russian Federation and Mongolia of January 20, 1993, and the Ulan Bator Declaration of November 14, 2000. They reached agreement in principle on the conduct in 2004 of an official visit to the Russian Federation by Mongolian President Bagabandi.

In examining key questions of bilateral relations, the importance was noted of implementing the Plan of Joint Action of the Government of the Russian Federation and the Government of Mongolia to Intensify Trade-and-Economic, Scientific-Technical and Cultural Ties in 2002-2004, and the agreements reached in the course of the official visit to Russia in June-July 2003 of Mongolian Prime Minister Enkhbayar.

The Sides emphasized the great importance of the settlement of the question of the credit indebtedness of Mongolia to the Russian Federation in transferable rubles for the further development of Russian-Mongolian relations. The terms of settlement reflect the historically established deep mutual trust, good-neighborliness and friendship between the peoples of Russia and Mongolia. The cardinal significance was noted of the principles for settlement, as agreed at the highest level during the official visit to Ulan Bator of President of the Russian Federation Vladimir Putin in 2000, as well as the agreements reached during the official visit to Mongolia of Chairman of the Government of the Russian Federation Mikhail Kasyanov in 2002 and the official visit to Moscow of Prime Minister of Mongolia Nambaryn Enkhbayar in 2003. The Sides regard the definitive solution of the question of the "big debt"; as a step opening favorable opportunities for the intensification of many-sided ties, including in the matter of resuming investment cooperation.

The Sides noted the coordinating role of the Russian-Mongolian Intergovernmental Commission on Trade-and-Economic and Scientific-Technical 
Cooperation and consider that the early implementation of the decisions and recommendations of its Tenth Meeting will help to impart new dynamics to the evolution of trade-and-economic ties and investment interaction, to the comprehensive deepening of cross-border and regional cooperation and to the expansion of exchanges in the fields of culture, science and education.

The importance was underlined of enhancing the effectiveness of the operations of the joint ventures Erdenet, Mongolrostsvetmet and Ulan Bator Railway, which are contributing substantially to bilateral cooperation and the development of the Mongolian economy.

Agreement was reached on the need to complete an inventory of the juridical base of Russian-Mongolian relations.

The Sides voiced satisfaction over the intensification of military and military technological cooperation and coordination and exchanges between special services and law enforcement and border agencies of the two countries.

During discussion of regional and international problems, they reaffirmed the identity or similarity of the approaches of Russia and Mongolia to key issues in world politics.

The Ministers of Foreign Affairs of Russia and Mongolia reaffirmed their countries' striving for more profound coordination on the international scene for the purpose of shaping a just and democratic world order based on strict observance of the Charter of the United Nations, the principles and rules of international law, universal security, sovereign equality and mutual consideration for the interests of all states.

There was underscored the need to resolve any issues and crisis situations by politico-diplomatic means on the basis of UN Security Council decisions. In this connection mutual support was expressed for efforts to build up the peacekeeping potential of the UN and to strengthen the Organization's role as the chief mechanism for collective regulation of international relations.

The Sides believe that in the new international security conditions, all possible maintenance of global strategic stability, the active stimulation of the disarmament process and the strengthening of multilateral arms control, and the effective prevention of the proliferation of weapons of mass destruction and their delivery vehicles meet the interests of all states.

The Sides will cooperate in the struggle against various global challenges and threats, in particular, those posed by international terrorism in all its forms and manifestations, transnational organized crime, illicit drug trafficking, money 
laundering, infectious diseases, environment degradation, the illicit trade in arms and humans, natural disasters and other complex emergency situations.

They also took note of the necessity to take coordinated collective measures to make the process of globalization more governable so as to ensure a maximally even distribution of the benefits and costs it brings between all the members of the world community.

The Ministers welcome the Ulan Bator Declaration and the Plan of Action: democracy, wise governance and civil society, adopted at the Fifth International Conference of New or Restored Democracies held in Ulan Bator on September 10-12, 2003. The Russian Side highly evaluates the contribution of the Government of Mongolia to holding this conference successfully, and attaches great importance to its results. The heads of the foreign affairs agencies of the Russian Federation and Mongolia spoke for the need for active cooperation in the follow-up to the Fifth International Conference and the consolidation of additional efforts to determine possible measures with a view to support of the actions of governments in the development and strengthening of the new or restored democracies, including the measures set forth in the Ulan Bator Declaration and the Plan of Action.

The Sides advocate reinforcing security and cooperation in the AsiaPacific Region and, in particular, in Northeast Asia and reaffirm their commitment to the development of multilateral cooperative approaches to the resolution of existing problems in the interest of safeguarding regional stability and security by politico-diplomatic means.

In this connection the Sides speak out in favor of further strengthening the role of the ASEAN Regional Forum (ARF) as a political institution of region wide importance and an effective instrument for interstate dialogue on maintaining peace and stability in the AP region. The Sides express mutual interest in building up cooperation in the framework of the ARF and in enhancing the effectiveness of the region's other structures and mechanisms of multilateral ties on the basis of the principles of openness and the equality of all the participants.

The Sides emphasized the necessity to continue efforts for creating a mechanism of political dialogue in Northeast Asia to discuss the issues of regional stability, security and cooperation. In this connection the Russian Side reaffirmed its support of the proposals concerning the development of a multilateral dialogue in Northeast Asia, put forward by Mongolia in 2000. 
In relation to the official start of the work in Beijing of the Secretariat of the Shanghai Cooperation Organization, the Sides reached agreement to hold regular consultations on the principal tasks of this new regional international forum, including a discussion of the possibility of Mongolia joining in the activities of the SCO in some or other form.

The Sides completely support the efforts aimed at a negotiated settlement of the DPRK nuclear problem on the basis of ensuring the nuclear-free status of the Korean Peninsula, as well as providing security guarantees and establishing normal conditions for the socioeconomic development of the DPRK. They favor the earliest possible continuation of the six-way negotiating process begun in Beijing, and a quest for mutually acceptable agreements which would contribute to the affirmation of peace, security and cooperation on the Korean Peninsula and in Northeast Asia as a whole.

The Ministers spoke for a comprehensive and just settlement of the conflict in the Middle East on the basis of UN Security Council resolutions 242, 338, 1397 and 1515, the principles of the Madrid Conference, including the Land for Peace principle, and the existing agreements and understandings. Common opinion was expressed that the Road Map, drawn up by the Quartet of International Mediators, Russia, the US, EU and UN, is an alternative plan for resolving the present crisis and advancing towards the establishment of an enduring peace in the Middle East region in which two independent states, Israel and Palestine, will coexist side by side within recognized and secure borders.

The Sides expressed concern over the continuing explosive situation in Iraq and the growth of terrorist activity there. The Ministers spoke for the early transfer of sovereignty to the people of Iraq through the adoption of a new constitution and formation of a lawful government as a result of democratic elections in accordance with UNSCR 1511.

The Sides welcome the agreements reached between India and Pakistan on a cease-fire and on the resumption from January 2004 of air links and transit overflights. They count on the implementation of these agreements, as well as the earlier initiatives put forward by New Delhi and Islamabad, to aid the settlement of the entire range of Indian-Pakistani relations and the resumption of dialogue on the basis of the Simla Agreement and the Lahore Declaration, believing that this would be in keeping with the interests of India and Pakistan and the cause of peace and security on the South Asian subcontinent. 
The Sides discussed the situation in Afghanistan and declared their full support of international efforts aimed at Afghanistan's revival and its reemergence as a peaceful, prosperous, integral and independent state. Noting that noninterference in the internal affairs of Afghanistan serves as a decisive factor in restoring peace and stability, they called on Afghanistan's neighboring states to fulfill their obligations, formulated in the Kabul Declaration on GoodNeighborly Relations, signed on December 22, 2002. The Sides expressed concern over the increased subversive and terrorist activity being carried out by remnants of the Taliban Movement and Al-Qaida and over the significant growth of drugs production in Afghanistan and their illicit marketing.

Plan of Cooperation between the Ministry of Foreign Affairs of the Russian Federation and the Ministry of Foreign Affairs of Mongolia for 2004-2005 was signed during the visit.

Igor Ivanov invited Mongolian Minister of Foreign Affairs Luvsangiin Erdenechuluun to pay an official visit to Russia. The invitation was accepted with gratitude. The date of the visit will be arranged via diplomatic channels.

\author{
MINISTER OF FOREIGNAFFAIRS OF THE \\ RUSSIAN FEDERATION IGOR IVANOV \\ MINISTER OF FOREIGNAFFAIRS OF \\ MONGOLIALUVSANGIINERDENECHULUUN
}

